\title{
MONITORING RYNKU PROGRAMÓW GEODEZYJNYCH WYKORZYSTYWANYCH DO OPRACOWANIA MAPY DO CELÓW PROJEKTOWYCH NA TERENIE POWIATU KRAKOWSKIEGO
}

\begin{abstract}
W niniejszym artykule przedstawiono ekonomiczny, techniczny i użytkowy aspekt wykorzystania programów komputerowych do realizacji jednej z najczęściej wykonywanych prac geodezyjnych, opracowania mapy do celów projektowych. Badania przeprowadzono w odniesieniu do czterech najczęściej stosowanych programów: MicroStation z nakładką MK2013, C-Geo, EwMapa, MikroMap. Wybór programów oparto o wyniki badań ankietowych przeprowadzonych wśród 30 wybranych losowo firm działających na terenie powiatu krakowskiego. Ocenę użyteczności wskazanych programów wykonano na bazie pomiaru sytuacyjno-wysokościowego wybranego obiektu wielkokubaturowego. Dane w postaci współrzędnych punktów w terenie pozyskano przy zastosowaniu najnowszych technologii pomiarowych. Nadrzędnym celem przeprowadzonych badań była próba weryfikacji możliwości wykorzystania niniejszych programów pod kątem wymogów stawianych wykonawcom prac geodezyjnych przez Ośrodki Dokumentacji Geodezyjnej i Kartograficznej. Całość zagadnienia rozpatrzono w aspekcie aktualnie obowiązujących przepisów prawa, dotyczących aktualizacji mapy zasadniczej.
\end{abstract}

Słowa kluczowe: mapa do celów projektowych, programy geodezyjne

\footnotetext{
${ }^{1}$ Autor do korespondencji: Monika Mika, Uniwersytet Rolniczy w Krakowie, Al. Mickiewicza 21, 31-120 Kraków, 12-66245-39, momika@ar.krakow.pl

2 Anna Przewięźlikowsk, AGH w Krakowie, WGGiIŚ, Katedry Geomatyki, Al. Mickiewicza 30, 30-059 Kraków, 126173892, przewie@agh.edu.pl

${ }^{3}$ Monika Siejka, Uniwersytet Rolniczy w Krakowie, Al. Mickiewicza 21, 31-120 Kraków, 12-66245-39,rmwiech@cyf-kr.edu.pl,
} 


\section{Wstęp}

W Polsce powinna obowiązywać zasada jednolitości prac geodezyjnych, polegająca na zastosowaniu następujących kryteriów: jednolitego systemu miar, jednolitego systemu odniesień przestrzennych, stałego poziomu odniesienia wysokości, obowiązujących odwzorowań kartograficznych, znormalizowanych zasad prowadzenia prac geodezyjnych [7].

Do dnia 13 stycznia 2015 r. obowiązywały przepisy rozporządzenia Ministra Administracji i Cyfryzacji z dnia 12 lutego 2013 r. w sprawie bazy danych geodezyjnej ewidencji sieci uzbrojenia terenu, bazy danych obiektów topograficznych oraz mapy zasadniczej [11]. Na czas zawieszenia tego przepisu Główny Geodeta Kraju informuje, że zadania Służby Geodezyjnej i Kartograficznej, w szczególności dotyczące prowadzenia powiatowej i krajowej bazy danych geodezyjnej ewidencji sieci uzbrojenia terenu, bazy danych obiektów topograficznych o szczegółowości zapewniającej tworzenie standardowych opracowań kartograficznych w skalach 1:500-1:5000 oraz mapy zasadniczej, powinny być realizowane zgodnie z zapisami ustawy z dnia 17 maja 1989 r. - Prawo geodezyjne i kartograficzne [12]. W chwili obecnej trwają zaawansowane prace przy tworzeniu aktów prawnych przez organy państwowe, a opracowywane projekty rozporządzeń Ministra Administracji i Cyfryzacji w sprawie bazy danych obiektów topograficznych oraz mapy zasadniczej, a także w sprawie powiatowej bazy GESUT i krajowej bazy GESUT wraz ze zgłoszonymi na wszystkich etapach uwagami są publikowane na stronach Rządowego Centrum Legislacji, Ministerstwa Administracji i Cyfryzacji oraz Głównego Urzędu Geodezji i Kartografii [GUGiK]. Wobec zaistniałej sytuacji prawnej - przy redakcji mapy do celów projektowych w praktyce geodezyjnej stosuje się oznaczenia i symbole ustalone przepisami dotyczącymi mapy zasadniczej i GESUT. Wynika to $\mathrm{z}$ faktu, że mapa do celów projektowych jest opracowaniem powstałym na bazie aktualnej mapy zasadniczej. $\mathrm{W}$ świetle rozporządzenia $\mathrm{W}$ sprawie mapy zasadniczej [11], mapa zasadnicza stała się więc standardowym opracowaniem kartograficznym. Można jednak zauważyć znaczne różnice w sposobach jej opracowywania, wynikające w głównej mierze z zastosowania różnego rodzaju oprogramowania.

W niniejszym artykule podjęto tematykę z zakresu ekonomicznego, technicznego i użytkowego aspektu wykorzystania programów geodezyjnych, stosowanych w grupie badanych firm geodezyjnych, do opracowania mapy do celów projektorych. Badania przeprowadzono w odniesieniu do czterech najczęściej stosowanych programów: MicroStation z nakładką MK2013 Power, CGeo, EwMapa i MikroMap. Obszar badań został zawężony do terenu powiatu krakowskiego.

Głównym celem publikacji jest analiza możliwości technicznych wybranych programów geodezyjnych pod kątem spełniania wymogów formalnoprawnych importu oraz eksportu danych przestrzennych pomiędzy różnymi sys- 
temami w formacie GML [10]. Od czasu informatyzacji zasobu geodezyjnego i kartograficznego pojawiały się w przepisach prawa dotyczących wymiany danych geodezyjnych, różne formaty, za pomocą których miały być przekazywane dane pomiędzy wykonawcami oraz Ośrodkami Dokumentacji Geodezyjnej i Kartograficznej. Dla celów niniejszej publikacji przeprowadzono monitoring rynku programów geodezyjnych wykorzystywanych do opracowania mapy do celów projektowych na terenie powiatu krakowskiego.

\section{Sondaż rynku geodezyjnego}

W celu wytypowania najczęściej używanych programów geodezyjnych na terenie powiatu krakowskiego, została przeprowadzona ankieta telefoniczna, zawierająca trzy zasadnicze pytania. Ankieta skierowana była do 30 losowo wybranych firm geodezyjnych. Wyniki ankiety miały posłużyć do oceny funkcjonalności programów przez praktykujących czynnie geodetów.

Zakres pytań ankietowych dotyczył następujących kwestii:

- nazw wykorzystywanych programów do kartowania map do celów projektowych,

- oceny poziomu ich użyteczności przez respondentów (w skali od 1 do 5),

- perspektyw zmian na inne oprogramowanie (jeżeli TAK, to na jakie).

Na potrzeby sondażu rynku geodezyjnego wybrano firmy o różnym stopniu rozwoju, od firm jednoosobowych do firm zatrudniających kilkunastu pracowników. Badania wykazały, że $40 \%$ firm wykorzystuje program MicroStation, $17 \%$ firm wykorzystuje program C-geo, $13 \%$ program ewMapa, $10 \%$ program MicroMap, po 7\% programy AutoCad oraz GeoKart, po $3 \%$ programy GeoMap i TurboMap. Można więc stwierdzić, że MicroStation jest sprawdzoną, stabilną i wydajną platformą CAD, wykorzystywaną przez większość biur geodezyjnych w powiecie krakowskim (tabela 1).

Tabela 1. Wyniki sondażu

Table 1. Questionnaire results

\begin{tabular}{|c|c|c|c|c|c|c|c|c|}
\hline \multicolumn{9}{|c|}{$\begin{array}{l}\text { NAZWA PROGRAMU WYKORZYSTYWANEGO DO OPRACOWANIA MAP DO } \\
\text { CELÓW PROJEKTOWYCH }\end{array}$} \\
\hline Wyszczególnienie & 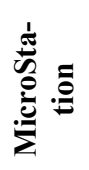 & Uై & 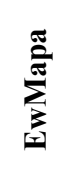 & 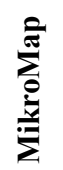 & 㐏 & Uूँ & $\sum_{0}^{\frac{\pi}{\pi}}$ & 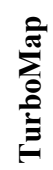 \\
\hline $\begin{array}{l}\text { LICZBA } \\
\text { UŻYTKOWNIKóW }\end{array}$ & 12 & 5 & 4 & 3 & 2 & 2 & 1 & 1 \\
\hline ŚREDNIA OCEN & 4,5 & 3,6 & 3,25 & 3 & 4,5 & 4 & 3 & 3 \\
\hline $\begin{array}{l}\text { LICZBA } \\
\text { DEKLARACJI ZMIAN } \\
\text { OPROGRAMOWANIA }\end{array}$ & 0 & 0 & 0 & 1 & 0 & & 1 & 1 \\
\hline
\end{tabular}


$\mathrm{Na}$ podstawie analizy wyników zawartych w tabeli 1 można zauważyć, że w 12 spośród 30 ankietowanych firm, do tworzenia mapy do celów projektowych wykorzystuje się program MicroStation firmy Bentley, do którego większość firm stosuje nakładkę MK2012 lub MK2013. Potwierdza to ogólny pogląd, że MicroStation jest sprawdzoną, stabilną i wydajną platformą CAD. Podobnie funkcjonującą platformą, działającą w środowisku CAD, jest program AutoCad. W badanej grupie zaledwie dwóch użytkowników zdeklarowało wykorzystywanie tego oprogramowania.

\section{Charakterystyka porównawcza najezęściej używanych pro- gramów}

Wytypowane w drodze przeprowadzonego sondażu programy geodezyjne można porównać pod względem technicznym, ekonomicznym i funkcjonalnym. W tabelach 2,3,4 przedstawiono zestawienie ich cech użytkowych według wybranych kryteriów porównawczych. Porównanie dotyczy czterech najbardziej popularnych programów wymienionych przez respondentów. Są to następujące programy: MicroStation+MK2013, C-Geo, MikroMap oraz EwMapa.

Tabela 2. Porównanie kosztów zakupu wybranych wersji grupy badanych programów

Table 2. Comparison purchase of selected versions of the programs examined group

\begin{tabular}{|c|c|c|c|c|}
\hline \multicolumn{5}{|c|}{$\begin{array}{l}\text { NAZWA PROGRAMU WYKORZYSTYWANEGO DO OPRACOWANIA MAP DO } \\
\text { CELÓW PROJEKTOWYCH }\end{array}$} \\
\hline Wyszczególnienie & 离 & نُ & 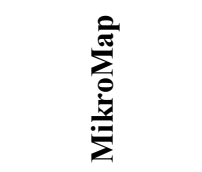 & $\sum_{i=1}^{\stackrel{\pi}{\pi}}$ \\
\hline Producent & $\begin{array}{l}\text { Bentley }+ \\
\text { GeoDeZy }[13]\end{array}$ & Softline [16] & Coder $[14]$ & $\begin{array}{l}\text { GEOBID } \\
{[15]}\end{array}$ \\
\hline Najnowsza wersja & $\begin{array}{l}\text { MicroStation } \\
\text { V8i } \\
\text { MK2013 }\end{array}$ & C-Geo V 8.0 & MikroMap 5.0 & $\begin{array}{l}\text { EwMapa } \\
11\end{array}$ \\
\hline $\begin{array}{l}\text { Koszt zakupu pod- } \\
\text { stawowej pełnej } \\
\text { wersji } \\
\text { (ceny netto) }\end{array}$ & $\begin{array}{l}\text { 6330zł Po- } \\
\text { werSurvey } \quad+ \\
2000 z ł \\
\text { MK2013 }\end{array}$ & $\begin{array}{l}1200 \mathrm{zł} \\
(\mathrm{z} \text { modułem kali- } \\
\text { bracji rastra i } \\
\text { z rocznym dostę- } \\
\text { pem do aktualizacji) }\end{array}$ & $200 \mathrm{zł}$ & $4990 \mathrm{zł}$ \\
\hline $\begin{array}{l}\text { Koszt zakupu naj- } \\
\text { bardziej rozbudo- } \\
\text { wanej wersji (cena } \\
\text { netto) }\end{array}$ & $\begin{array}{l}\text { MicroStation } \\
\text { V8i } \\
\text { MK2013 } \\
20100 \mathrm{zt}+ \\
\end{array}$ & $\begin{array}{l}\text { 5300zł (ze wszyst- } \\
\text { kimi dostępnymi } \\
\text { modułami) }\end{array}$ & $\begin{array}{l}400 \mathrm{zl} \quad \mathrm{z} \\
\text { wszystkimi } \\
\text { modułami }\end{array}$ & $\begin{array}{l}\text { EwMapa } \\
11 \mathrm{FB} \\
5290 \mathrm{zł}\end{array}$ \\
\hline
\end{tabular}




\begin{tabular}{|c|c|c|c|c|}
\hline \multicolumn{5}{|c|}{$\begin{array}{l}\text { NAZWA PROGRAMU WYKORZYSTYWANEGO DO OPRACOWANIA MAP DO } \\
\text { CELÓW PROJEKTOWYCH }\end{array}$} \\
\hline Wyszczególnienie & 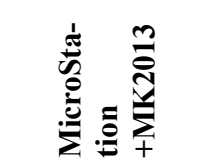 & Џُّ & 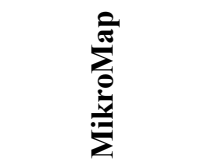 & 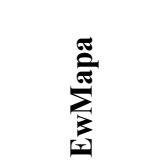 \\
\hline & $2000 \mathrm{zt}$ & & & \\
\hline $\begin{array}{l}\text { Upgrade } \mathrm{z} \text { wersji } \\
\text { starszej }\end{array}$ & $\begin{array}{l}\text { brak informa- } \\
\text { cji }\end{array}$ & $\begin{array}{l}\text { 600zł } \\
\text { upgrade C-Geo z } \\
\text { edycji } 2013 \text { lub } \\
\text { starszej do edycji } \\
2015\end{array}$ & $\begin{array}{l}\text { różnica ce- } \\
\text { ny/bezpłatnie }\end{array}$ & $\begin{array}{l}1890 \mathrm{zl} \quad \mathrm{z} \\
\text { wersji } 10 \\
2190 \mathrm{zl} \quad \mathrm{z} \\
\text { pozosta- } \\
\text { łych wersji }\end{array}$ \\
\hline $\begin{array}{l}\text { Koszt aktualizacji } \\
\text { (ceny netto) }\end{array}$ & $\begin{array}{l}\text { brak informa- } \\
\text { cji }\end{array}$ & $\begin{array}{l}\text { 200,00zł roczne } \\
\text { wznowienie aktuali- } \\
\text { zacji }\end{array}$ & bezpłatne & $\begin{array}{l}\text { bezpłatne } \\
\text { do danej } \\
\text { wersji }\end{array}$ \\
\hline $\begin{array}{l}\text { Koszt nakła- } \\
\text { dek/modułów } \\
\text { (ceny netto) }\end{array}$ & $\begin{array}{l}\text { MK2013 } \\
2000 z 1\end{array}$ & $\begin{array}{l}\text { łączny koszt } 4100 z ł \\
\text { netto }\end{array}$ & $\begin{array}{lr}\text { każdy moduł } \\
\text { 50zł, łącznie } \\
\text { 200zł }\end{array}$ & $\begin{array}{l}\text { brak nakła- } \\
\text { dek }\end{array}$ \\
\hline $\begin{array}{l}\text { Ilość obsługiwa- } \\
\text { nych stanowisk na } \\
1 \text { licencję/klucz }\end{array}$ & 1 & 1 & $\begin{array}{l}1 \\
\text { każde następ- } \\
\text { ne } 50 \% \text { ceny }\end{array}$ & $\begin{array}{l}\text { klucze } 1, \\
10 \text { lub } 50 \\
\text { stanowi- } \\
\text { skowe }\end{array}$ \\
\hline $\begin{array}{l}\text { Koszt klucza sprzę- } \\
\text { towego, ilość sta- } \\
\text { nowisk } \\
\text { (ceny netto) }\end{array}$ & $\begin{array}{l}\text { jeden klucz, } \\
\text { jedno stano- } \\
\text { wisko } \\
\text { brak informa- } \\
\text { cji o cenie }\end{array}$ & $\begin{array}{l}\text { 150zł } \\
\text { umożliwia legalne } \\
\text { przenoszenie C-Geo } \\
\text { między komputera- } \\
\text { mi bez dodatko- } \\
\text { wych licencji }\end{array}$ & $\begin{array}{l}\text { kod odbloko- } \\
\text { wujący dwa } \\
\text { stanowiska, } \\
\text { niejednocze- } \\
\text { śnie używane }\end{array}$ & $\begin{array}{l}\text { jednosta- } \\
\text { nowi- } \\
\text { skowy } \\
\text { klucz do } \\
\text { programu } \\
\text { EwMapa } \\
990 \mathrm{zt}\end{array}$ \\
\hline Wersja demo & $\begin{array}{l}\text { tak }-30- \\
\text { dniowa } \quad \mathrm{W} \\
\text { pełni funkcjo- } \\
\text { nalna }\end{array}$ & $\begin{array}{l}\text { tak, 30-dniowa, } \\
\text { okrojone możliwo- } \\
\text { ści }\end{array}$ & $\begin{array}{l}\text { tak - } 30 \text { dnio- } \\
\text { wa w pełni } \\
\text { funkcjonalna }\end{array}$ & $\begin{array}{l}\text { tak - ogra- } \\
\text { niczenia na } \\
\text { ilość da- } \\
\text { nych }\end{array}$ \\
\hline
\end{tabular}

Z przeprowadzonej analizy porównawczej wynika, że najwyższe koszty dla firm, generuje zakup programu MicroStation z nakładką MK2013. Najtańszym oprogramowaniem jest MikroMap, ale jego możliwości techniczne są mniejsze.

$\mathrm{W}$ tabeli 3 przedstawiono analizę porównawczą możliwości technicznych grupy wybranych programów.

Na podstawie analizy porównawczej zawartej w tabeli 3 zauważyć można, że zarówno program MicroStation oraz C-Geo obsługują różne formaty plików, zarówno w zakresie eksportu jak i importu danych. Zaletą obu programów jest możliwość zastosowania na urządzeniach mobilnych. 
Tabela 3. Porównanie możliwości technicznych grupy wybranych programów

Table. 3. Comparison of the technical possibilities groups selected programs

\begin{tabular}{|c|c|c|c|c|}
\hline \multicolumn{5}{|c|}{$\begin{array}{l}\text { NAZWA PROGRAMU WYKORZYSTYWANEGO DO OPRACOWANIA MAP DO } \\
\text { CELÓW PROJEKTOWYCH }\end{array}$} \\
\hline $\begin{array}{l}\text { Atrybuty tech- } \\
\text { niczne }\end{array}$ & $\begin{array}{l}\text { MicroStation } \\
+ \text { MK2013 }\end{array}$ & C-Geo & MikroMap & EwMapa \\
\hline $\begin{array}{l}\text { Częstotliwość } \\
\text { aktualizacji }\end{array}$ & $\begin{array}{l}\text { stale aktualizowa- } \\
\text { ny }\end{array}$ & $\begin{array}{l}\text { stale aktualizo- } \\
\text { wany }\end{array}$ & $\begin{array}{l}\text { stale aktuali- } \\
\text { zowany }\end{array}$ & $\begin{array}{l}\text { stale aktuali- } \\
\text { zowany }\end{array}$ \\
\hline $\begin{array}{l}\text { Polska wersja } \\
\text { języko- } \\
\text { wa/obcojęzyczna } \\
\text { wersja }\end{array}$ & tak/tak & tak/nie & tak/nie & tak/nie \\
\hline $\begin{array}{l}\text { Przejrzystość } \\
\text { interfejsu }\end{array}$ & $\begin{array}{l}\text { przejrzysty, roz- } \\
\text { budowany }\end{array}$ & $\begin{array}{l}\text { rozbudowany, } \\
\text { mało przejrzy- } \\
\text { sty }\end{array}$ & $\begin{array}{l}\text { przejrzysty, } \\
\text { prosty }\end{array}$ & $\begin{array}{l}\text { rozbudowany, } \\
\text { przejrzysty }\end{array}$ \\
\hline $\begin{array}{l}\text { Wymagania } \\
\text { sprzętowe } \\
\text { minimalne }\end{array}$ & $\begin{array}{l}\text { procesor: Pentium } \\
\text { 900Hz, } \\
\text { system operacyj- } \\
\text { ny: Windows } \\
\text { 2000/XP/Vista/7/ } \\
\text { 8, Linux } \\
\text { pamięć: 512MB, } \\
\text { zalecane 1GB } \\
\text { twardy dysk: 1GB } \\
\text { urządzenie wska- } \\
\text { zujące: myszka }\end{array}$ & $\begin{array}{l}\text { Windows } \\
\text { XP/VISTA/7/8/ } \\
\text { Linux. wyma- } \\
\text { gania sprzęto- } \\
\text { we: Pentium IV, } \\
2 \text { GB RAM, } \\
\text { Karta grafiki } \\
512 \mathrm{Mb} \text { ram, } 10 \\
\text { GB wolnego na } \\
\text { twardym dysku } \\
\text { na program }\end{array}$ & $\begin{array}{l}\text { wymagania } \\
\text { sprzętowe: } \\
486 \text { DX, } 64 \\
\text { MB pamięci } \\
\text { RAM, } 8 \text { MB } \\
\text { wolnego miej- } \\
\text { sca na dysku. } \\
\text { Program pra- } \\
\text { cuje w srodo- } \\
\text { wisku Win- } \\
\text { dows 98, NT, } \\
\text { Me, 2000, } \\
\text { XP/Vista/7/8 }\end{array}$ & $\begin{array}{l}\text { wymagania } \\
\text { sprzętowe: } \\
\text { można uru- } \\
\text { chomić na } \\
\text { każdym kom- } \\
\text { puterze z pro- } \\
\text { cesorem lep- } \\
\text { szym niż PIII } \\
500 \mathrm{MHz} \\
\text { system opera- } \\
\text { cyjny: Win- } \\
\text { dows } \\
2000 / \mathrm{XP} / \text { Vist } \\
\text { a/7/8 }\end{array}$ \\
\hline $\begin{array}{l}\text { Możliwość insta- } \\
\text { lowania nakła- } \\
\text { dek/modułów }\end{array}$ & tak & tak & tak & nie \\
\hline $\begin{array}{l}\text { Formaty obsługi- } \\
\text { wanych plików - } \\
\text { import }\end{array}$ & $\begin{array}{l}\text { IGES, Parasol- } \\
\text { ids,ACIS } \\
\text { CGM, SAT, } \\
\text { AP203/AP214, } \\
\text { STL, CAD files, } \\
\text { TerrainModel, } \\
\text { Image, TXT }\end{array}$ & 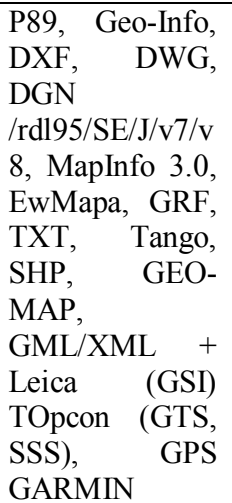 & $\begin{array}{l}\text { DWG, DXF, } \\
\text { DGN v7, } \\
\text { EwMapa, } \\
\text { TANGO, } \\
\text { GEO-MAP, } \\
\text { SWDE, SHP, } \\
\text { TXT, P89, } \\
\text { EWA }\end{array}$ & $\begin{array}{l}\text { TXT, } \\
\text { DXF }\end{array}$ \\
\hline $\begin{array}{l}\text { Formaty zapisu } \\
\text { danych - eksport }\end{array}$ & $\begin{array}{l}\text { DGN, DWG, } \\
\text { DXF, IGES, Para- } \\
\text { solids, ACIS SAT, } \\
\text { CGM, Step } \\
\text { Ap203/AP214, }\end{array}$ & $\begin{array}{l}\text { P89, Geo-info, } \\
\text { DXF, DWG, } \\
\text { SVG, MapInfo, } \\
\text { GDN v7, EW- } \\
\text { Mapa, WMF, }\end{array}$ & 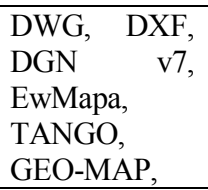 & $\begin{array}{l}\text { TXT,SHP,DX } \\
\text { F,HTML }\end{array}$ \\
\hline
\end{tabular}




\begin{tabular}{|c|c|c|c|c|}
\hline \multicolumn{5}{|c|}{$\begin{array}{c}\text { NAZWA PROGRAMU WYKORZYSTYWANEGO DO OPRACOWANIA MAP DO } \\
\text { CELÓW PROJEKTOWYCH }\end{array}$} \\
\hline $\begin{array}{l}\text { Atrybuty tech- } \\
\text { niczne }\end{array}$ & $\begin{array}{l}\text { MicroStation } \\
+ \text { MK2013 }\end{array}$ & C-Geo & MikroMap & EwMapa \\
\hline & $\begin{array}{lr}\text { VRML, } & \text { STL, } \\
\text { SVG, Luxology, } \\
\text { OBJ, } \\
\text { SketchUp, Google } \\
\text { Earth, } & \text { Collada, } \\
\text { U3D, JT } & \end{array}$ & $\begin{array}{l}\text { SWING, TXT, } \\
\text { TANGO, SHP, } \\
\text { GML/XML, } \quad+ \\
\text { LEICA GSI, }\end{array}$ & $\begin{array}{l}\text { SWING, } \\
\text { SWDE,SHP, } \\
\text { BMP }\end{array}$ & \\
\hline $\begin{array}{l}\text { Współpraca } \\
\text { tachimetrami, } \\
\text { niwelatorami } \\
\text { kodowymi, kon- } \\
\text { trolerami GPS i } \\
\text { rejestratorami }\end{array}$ & nie & $\begin{array}{lr}\text { tak } & \text { Leica } \\
\text { (GSI) } & \text { Topcon } \\
\text { (GTS, } & \text { SSS), } \\
\text { GPS GARMIN }\end{array}$ & nie & nie \\
\hline $\begin{array}{l}\text { Programy na } \\
\text { urządzenia mobil- } \\
\text { ne }\end{array}$ & tak & tak & tak & nie \\
\hline
\end{tabular}

Istotnym czynnikiem w analizie możliwości technicznych programów geodezyjnych jest wymóg importu oraz eksportu danych przestrzennych pomiędzy różnymi systemami $\mathrm{w}$ formacie GML [10]. Od czasu informatyzacji zasobu geodezyjnego i kartograficznego pojawiały się w przepisach prawa dotyczących wymiany danych geodezyjnych, różne formaty, za pomocą których miały być przekazywane dane pomiędzy wykonawcami oraz Ośrodkami Dokumentacji Geodezyjnej i Kartograficznej. Pierwszym z nich był powołany w 1995 roku standard SWING [6], który miał służyć wymianie danych przestrzennych. Format ten nie był jednak wystarczająco jednoznaczny i importy danych nie kończyły się powodzeniem.

Kolejnym, wprowadzonym w 1998 roku, był format TANGO. Nie był on formalnie przyjęty przez GUGiK, ale z powodzeniem funkcjonował jako format do wymiany danych przestrzennych. Zawierał odpowiednie odwołania, które w prawidłowy sposób implementowały wytyczne podane w Instrukcji K-1 oraz GESUT. Format ten w konsekwencji przyjęty został w wielu programach, co potwierdza również badanie ankietowe zawarte w tabeli 3 .

W 2001 roku, wraz z wejściem w życie Rozporządzenia w sprawie EGiB [9], pojawił się Standard Wymiany Danych Ewidencyjnych SWDE. Schemat ten również zastosowany został $\mathrm{w}$ wielu programach geodezyjnych i dobrze sprawdził się jako podstawa przy tworzeniu systemów LPIS oraz IPE. Format SWDE został poszerzony do wersji SWING 3.0 i miał służyć do wymiany danych dla baz SIT, SIP oraz GIS. Standard ten przenosił elementy redakcyjne mapy, był często wykorzystywany w praktyce, a w 2006 roku powstały wytyczne techniczne do wymiany danych ewidencyjnych również $\mathrm{w}$ trybie różnicowym [8]. 
W konsekwencji powstawania kolejnych specyficznych formatów do wymiany danych, rozpoczęto prace nad zastosowaniem formatu danych XML, który jest naturalnym formatem do wymiany danych w sieci WWW, jako uniwersalnego formatu, który mógłby służyć również geodezji. Językiem opartym na XML, służącym do opisu danych przestrzennych, jest obowiązujący w obecnych przepisach GML - Geography Markup Language: "(...) reprezentacja XML stużaca do transportu i przechowywania informacji geograficznej łaczacej zarówno właściwości przestrzenne jak i nieprzestrzenne obiektów geograficznych (...)" [6]. Standard ten jednak do dnia dzisiejszego praktycznie nie służy wymianie danych pomiędzy wykonawcami i ODGiK. Jak wykazano w [5] model ma wiele wad, do których należy zaliczyć: brak możliwości przenoszenia elementów redakcyjnych, model jest mało czytelny, model funkcjonował wyłącznie w sferze teoretycznej $\mathrm{i}$ istnieją spore trudności związane $\mathrm{z}$ zapisem informacji o wielu obiektach, problemy z zapisem geometrii.

Obecnie brak jednoznacznego sposobu zapisu danych przestrzennych oraz programu które w sposób pełny umożliwiałby wymianę danych w formacie GML pomiędzy ODGiK, a wykonawcą. Częściowo wymóg ten spełnia EwMapa, jednakże do zapisu i odczytu danych przestrzennych w formacie GML konieczne jest posiadanie tego programu. W tej sytuacji na dzień dzisiejszy wymiana danych następuje w większości przypadków zgodnie z §70.6 [10] w "(...) innym formacie uzgodnionym między wykonawca a organem prowadzacym PZGiK".

Tabela 4. Porównanie możliwości użytkowych (praktycznych) grupy wybranych programów

Table 4. Comparison of capabilities usable (practical) group of selected programs

\begin{tabular}{|c|c|c|c|c|}
\hline Wyszczególnienie & 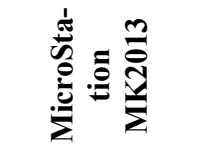 & 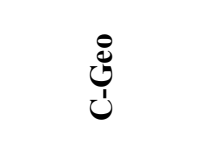 & 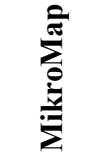 & 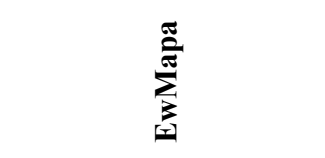 \\
\hline $\begin{array}{l}\text { Czas opracowania } \\
\text { mapy syt-wys }\end{array}$ & $1 \mathrm{~h}$ & $3 \mathrm{~h}$ & $2,5 \mathrm{~h}$ & $\begin{array}{l}\text { 5h, (konieczność utworze- } \\
\text { nia bazy danych obiektów } \\
\text { przestrzennych, a w na- } \\
\text { stępnej kolejności istnieje } \\
\text { możliwość generowania } \\
\text { mapy) }\end{array}$ \\
\hline $\begin{array}{l}\text { Intuicyjność obsługi } \\
\text { (skala od 1-5) }\end{array}$ & 5 & 4 & 3 & 3 \\
\hline Pomoc techniczna & $\begin{array}{l}\text { On-line/ } \\
\text { telefoniczna }\end{array}$ & $\begin{array}{l}\text { On-line/ } \\
\text { telefoniczna }\end{array}$ & On-line & $\begin{array}{l}\text { On-line/ } \\
\text { telefoniczna }\end{array}$ \\
\hline Instrukcja obsługi & $\begin{array}{l}\text { MicroStation } \\
\text { V8 - } 120 \text { str pdf } \\
\text { MK2013 - in- } \\
\text { strukcja w za- } \\
\text { kładce pomoc }\end{array}$ & $\begin{array}{l}\text { szczegółowa } \\
\text { pdf } 220 \text { str }\end{array}$ & $\begin{array}{l}\text { szcze- } \\
\text { gółowa } \\
109 \text { str. } \\
\text { Word } \\
97 \\
\end{array}$ & $\begin{array}{ll}\text { szczegółowa } & \text { instrukcja } \\
211 \text { str pdf } & \\
+ \text { podręcznik } & \text { EWmapa } \\
189 \text { str pdf } & \end{array}$ \\
\hline Szkolenia & $\begin{array}{l}\text { Szkolenia } \quad \text { z } \\
\text { obsługi opro- } \\
\text { gramowana }\end{array}$ & $\begin{array}{l}\text { Zestaw ćwiczeń } \\
\text { dla początkują- } \\
\text { cych, dział } \\
\text { wsparcie }\end{array}$ & Brak & Szkolenia z obsługi \\
\hline
\end{tabular}


Z zawartej w tabeli 4 analizy porównawczej wynika, że mapę do celów projektowych danego obiektu wykonać można w najkrótszym czasie w programie MicroStation + MK2013.

$\mathrm{Na}$ kolejnych rysunkach $(1,2,3,4)$ przedstawiono fragmenty mapy dla tego samego obiektu (Kopiec Józefa Piłsudskiego w Krakowie) wykonane w programach: MicroStation, C-Geo, MikroMap, EwMapa.

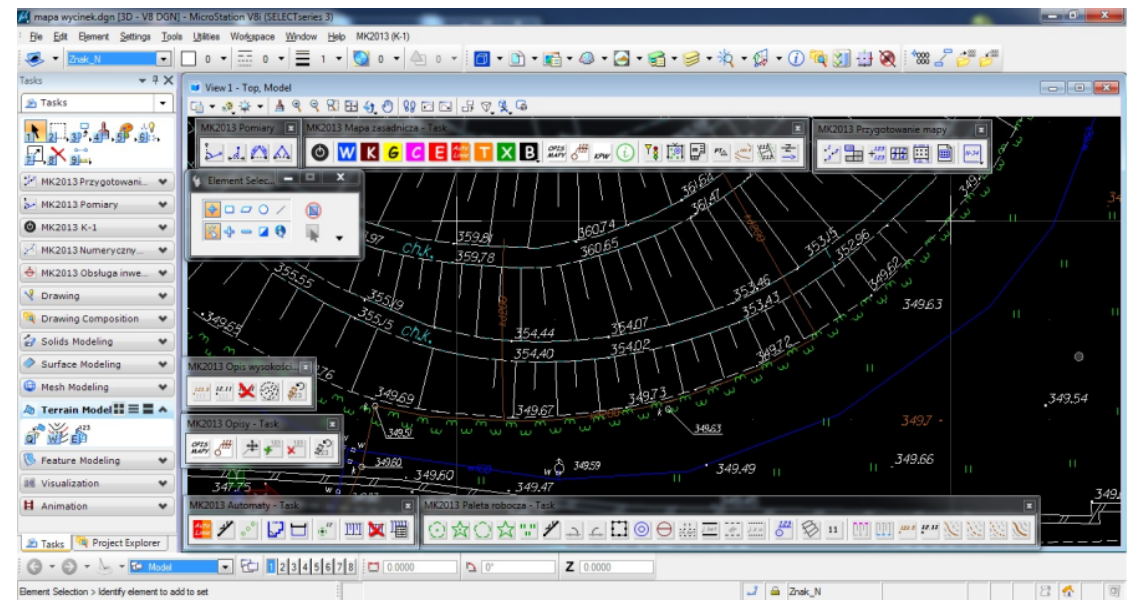

Rys.1. Fragment mapy wykonanej w programie MicroStation

Fig. 1. A fragment of a map developed in MicroStation program

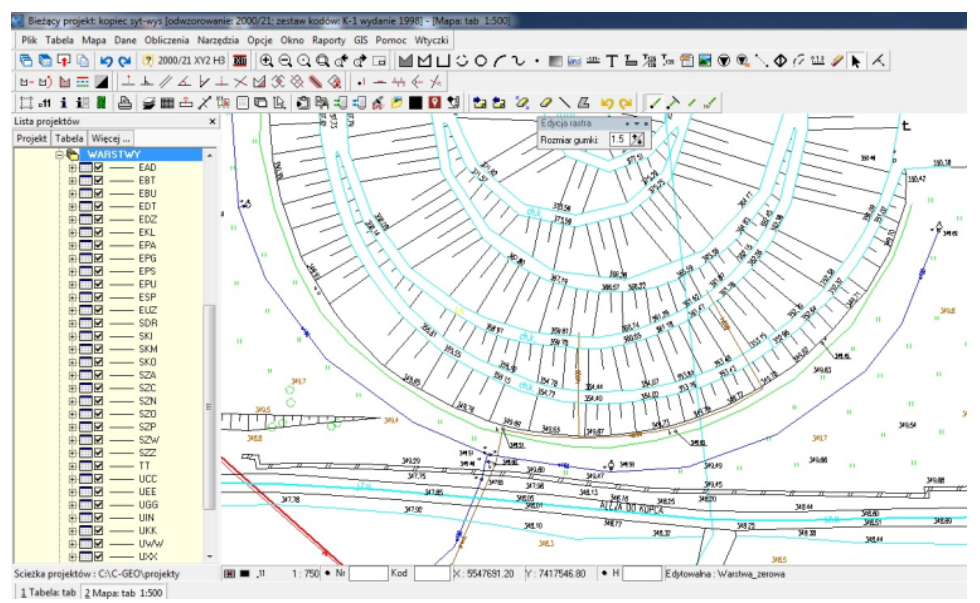

Rys.2. Fragment mapy wykonanej w programie C-Geo

Fig. 2. A fragment of a map developed in C-Geo program 


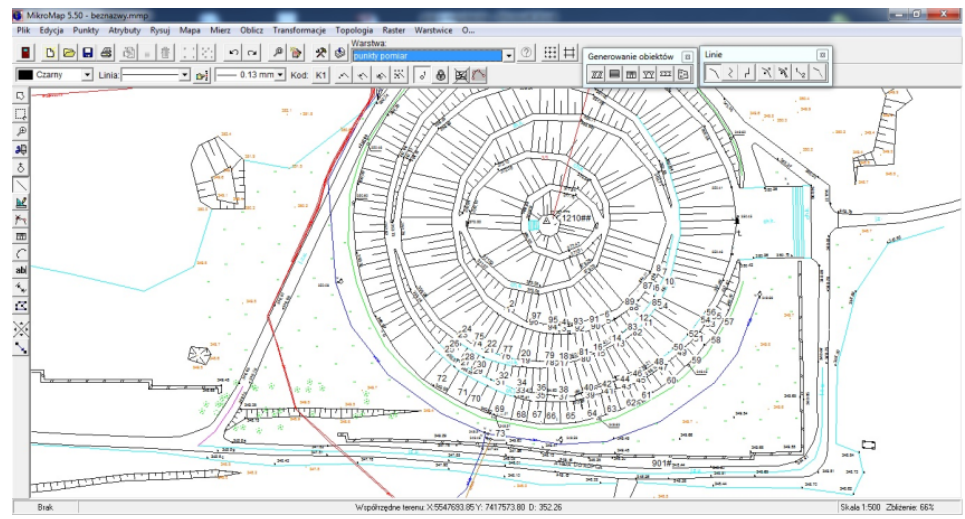

Rys. 3. Fragment mapy wykonanej w programie MikroMap

Fig. 3. A fragment of a map developed in MikroMap program

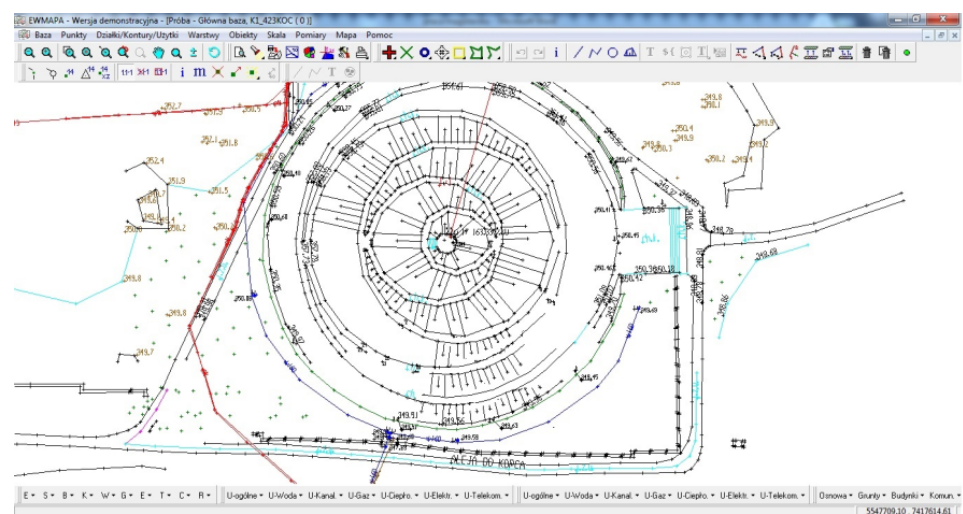

Rys. 4. Fragment mapy wykonanej w programie EwMapa

Fig. 4. A fragment of a map developed in EwMapa program

Tabela 5. Zestawienie zalet i wad grupy wybranych programów, w ocenie użytkowników

Table 5. Selection of the pros and cons of a group of selected programs, the evaluation users

\begin{tabular}{|c|c|c|}
\hline & Zalety & Wady \\
\hline $\begin{array}{l}\text { MicroStation } \\
+ \text { MK2013 }\end{array}$ & $\begin{array}{l}\text { - przejrzysty i intuicyjny interfejs } \\
\text { - liczne funkcje usprawniające karto- } \\
\text { wanie } \\
\text { - rozbudowane opcje rysowania, } \\
\text { - możliwość dostosowania funkcji do } \\
\text { własnych potrzeb } \\
\text { - liczne nakładki usprawniające pracę }\end{array}$ & $\begin{array}{l}\text { - wysoka cena } \\
\text { - duże wymagania sprzętowe }\end{array}$ \\
\hline MikroMap & $\begin{array}{l}\text { - prosty i przejrzysty interfejs } \\
\text { - łatwa obsługa } \\
\text { - niska cena }\end{array}$ & $\begin{array}{l}\text { - brak funkcji rozwiązywania typowych } \\
\text { zadań geodezyjnych } \\
\text { - kłopotliwa technika rysowania } \\
\text { - niewielkie możliwości }\end{array}$ \\
\hline
\end{tabular}




\begin{tabular}{|c|c|c|}
\hline C-Geo & $\begin{array}{l}\text { - przystępna cena, } \\
\text { - obliczenia i kartowanie mapy } \\
\text { w jednym programie } \\
\text { - szkolenia z zakresu obsługi }\end{array}$ & $\begin{array}{l}\text { - mało przejrzysty interfejs } \\
\text { - błędy przy imporcie plików dgn, dxf, } \\
\text { dwg } \\
\text { - obciążony zbędnymi funkcjami }\end{array}$ \\
\hline EwMapa & $\begin{array}{l}\text { - przejrzysty i rozbudowany interfejs } \\
\text { - duża ilość narzędzi graficznych } \\
\text { - możliwość wykonywania analiz } \\
\text { przestrzennych }\end{array}$ & $\begin{array}{l}\text { - kartowanie mapy czasochłonne, gdyż } \\
\text { w pierwszej kolejności należy utwo- } \\
\text { rzyć bazę danych obiektów prze- } \\
\text { strzennych, a w następnej kolejności } \\
\text { istnieje możliwość generowania mapy } \\
\text { - ograniczenia wersji demonstracyjnej }\end{array}$ \\
\hline
\end{tabular}

\section{Podsumowanie}

Zmieniająca się $\mathrm{w}$ szybkim tempie technika i technologie wykonywania pomiaru geodezyjnego wymagają od autorów oprogramowania branżowego ciągłych zmian w kierunku dostosowywania do potrzeb rynku [1], [2], [3], [4]. Dodatkowym czynnikiem wymuszającym tempo zmian jest systematyczny proces regulacji prawnych, w zakresie standardów technicznych, odnośnie warunków przeprowadzania pomiarów, wynikający z nowelizacji ustawy prawo geodezyjne i kartograficzne [12] oraz przepisów wykonawczych.

W oparciu o dane ankietowe przeprowadzono sondaż rynku geodezyjnego w zakresie najczęściej używanych programów. W celu sprawdzenia użyteczności tych programów wykonano mapy obiektu wielkokubaturowego. Program MicroStation z nakładką MK2013 okazał się najbardziej użyteczny. Pozwala on na wykonanie mapy w najkrótszym czasie. Z kolei, pod względem intuicyjności i komfortu obsługi, w grupie badanych programów wyróżnić należy program MikroMapa. Również w opinii respondentów został on wysoko oceniony, ze względu na łatwość obsługi i stosunkowo niską cenę. Najniżej oceniono programy C-Geo i EwMapa.

Analiza porównawcza wykazała, że najpopularniejszym i najbardziej użytecznym programem wykorzystywanym $\mathrm{w}$ kameralnym opracowaniu map do celów projektowych, przez firmy geodezyjne na terenie powiatu krakowskiego, jest program MicroStation z nakładką MK2013. Przez grupę badanych firm geodezyjnych został on wysoko oceniony. Zalety programu podkreśla fakt, iż żadna $\mathrm{z}$ badanych firm nie deklaruje wymiany tego oprogramowania na inne. Można więc domniemywać, że wszyscy użytkownicy są usatysfakcjonowani $\mathrm{z}$ walorów technicznych i użytkowych tego programu. Jako wadę tego progra$\mathrm{mu}$, respondenci podają wymagania sprzętowe, co w konsekwencji generuje wyższe koszty przygotowania stanowiska pracy, mając dodatkowo na względzie wysoką cenę samego oprogramowania.

Pod względem walorów użytkowych program MicroStation zyskał najwyższą ocenę wśród badanych firm, głównie ze względu na szerokie możliwości rysowania i modyfikacji map. Żaden z pozostałych testowanych programów nie dawał porównywalnych rezultatów. Z kolei, pod względem intuicyjności 
i komfortu obsługi, w grupie badanych programów, wyróżniono program MikroMapa. Najniższą ocenę natomiast zyskały programy C-Geo i EwMapa.

Przeprowadzona analiza wykazała elastyczność rynku geodezyjnego w zakresie dostosowywania programów branżowych do potrzeb użytkownika. Większość z nich to produkty niosące ze sobą wymierne i porównywalne efekty w zakresie tworzenia map. Różnią się jednak one ceną, możliwościami i komfortem pracy. Są to główne czynniki które musi dostosować indywidualnie każdy potencjalny nabywca. Problemem jednak okazuje się brak odpowiednich sformułowań prawnych w zakresie jednoznacznego sposobu zapisu danych przestrzennych oraz programu który w sposób pełny umożliwiałby wymianę danych w formacie GML pomiędzy ODGiK, a wykonawcą.

\section{Literatura}

[1] Czarnecki K.: Geodezja współczesna w zarysie, Wiedza i Życie, Warszawa 1996.

[2] Cymerman M.: Kontrola dokumentacji technicznej w ODGiK zgodnie z nowymi przepisami, Nowa Geodezja w Praktyce, Nr 2/2012.

[3] Cymerman M.: Pomiary sytuacyjne i wysokościowe zgodnie z nowym rozporządzeniem, Nowa Geodezja w Praktyce, Nr 1/2012.

[4] Hycner R., Hanus P.: Wykonawstwo geodezyjne, Gall, Katowice 2007

[5] Izdebski W.: http://www.izdebski.edu.pl/kategorie/Publikacje/ 2013_GML_Waldemar_Izdebski.pdf [dostęp 3 marca 2015r.]

[6] Iwaniak K: http://konferencjagml. kondor.pl/prezentacje/ 01_Iwaniak_ GML_w_praktyce_geodezyjnej.pdf, [dostęp 10 marca 2015r.].

[7] Jagielski A.: Geodezja I, Wydanie 2, Geodpis, Kraków 2005.

[8] Miksa K.: Wytyczne techniczne modułu wymiany danych ewidencyjnych (exportimport) $\mathrm{w}$ formacie SWDE/SWING w tym w trybie różnicowym, Załącznik nr 1 do „Warunków technicznych”, Opracował mgr inż. Krzysztof Miksa na zlecenie Głównego Urzędu Geodezji i Kartografii, Departamentu Katastru i Państwowego zasobu Geodezyjnego i Kartograficznego, Warszawa 2006.

[9] Rozporządzenie Ministra Rozwoju Regionalnego i Budownictwa z dnia 29 marca 2001 r. w sprawie ewidencji gruntów i budynków (Dz.U. $2001 \mathrm{nr} 38$ poz. 454).

[10] Rozporządzenie Ministra Spraw Wewnętrznych i Administracji z dnia 9 listopada 2011 r. w sprawie standardów technicznych wykonywania geodezyjnych pomiarów sytuacyjnych i wysokościowych oraz opracowywania i przekazywania wyników tych pomiarów do państwowego zasobu geodezyjnego i kartograficznego (Dz.U. $2011 \mathrm{nr} 263$ poz. 1572).

[11]Rozporządzenie Ministra Administracji i Cyfryzacji z dnia 12 lutego 2013 r. w sprawie bazy danych geodezyjnej ewidencji sieci uzbrojenia terenu, bazy danych obiektów topograficznych oraz mapy zasadniczej (Dz.U. 2013 poz. 383).

[12] Ustawa z dnia 17 maja 1989 r. - Prawo geodezyjne i kartograficzne (Dz. U. z 2010 r. $\mathrm{Nr}$ 193, poz. 1287, z późn. zm.).

[13] http://www.geodezy.com.pl

[14] http://www.coder.atomnet.pl

[15] http://geobid.pl

[16] http://softline.xgeo.pl 


\title{
MONITORING OF THE SURVEYING SOFTWARE MARKET WITH FOCUS ON APPLICATIONS USED TO DEVELOP MAPS FOR DESIGN PURPOSES IN THE DISTRICT OF KRAKOW
}

\begin{abstract}
S u m m a r y
This article presents an economic, technical and user's aspect of the use of software applications for one of the most frequently developed surveying, developing maps for design purposes. The study covered the four most commonly used programs: MicroStation with the overlay MK2013, C-Geo, EWMAPA and MikroMap. The choice of programs was based on the results of surveys conducted among a random sample of 30 companies operating in the district of Krakow. The evaluation the usefulness of the named programs was based on the topographic measurements of a selected large-area object. The data presented as terrain coordinates of points was collected in the field using the latest measurement technologies. The overall aim of the study was an attempt to verify the possibility of using these programs according to the requirements given to surveying contractors by the Geodesic and Cartographic Documentation Centers. The whole issue was examined in the context of the current regulations concerning the master map updates.
\end{abstract}

Keywords: map for design purposes, surveying software applications

Przestano do redakcji:30.05.2015

Przyjęto do druku:1.12.2015

DOI: $10.7862 / \mathrm{rb} .2015 .156$ 